\title{
Strategi Komunikasi Pemasaran yang Dilakukan Guten Morgen Coffee Lab and Shop untuk Menarik Konsumen
}

\author{
Leanora Theresiana, Yugih Setyanto \\ leanoratheresiana@gmail.com,yugihs@fikom.untar.ac.id \\ Fakultas Ilmu Komunikasi Universitas Tarumanagara
}

\begin{abstract}
Business development in Indonesia is growing more especially in culinary field. It can't be denied that is so much restaurant and cafe around us. Every business owner compete to create something unique to make an attention of their customer. This research is in purpose to know is Guten Morgen Coffee Lab and Shop's communication marketing strategy to interest customers. This research is using marketing communication concept. The method in use for this research is case study with qualitative approach method. Interactive data analyses is used in order to analyze the research data. Besides using observation and literature review, researcher is also doing unstructured interview with the owner of the coffee shop and the consumer to supporting the research data. The results of researchs found that the coffee shop in conducting marketing communication strategy by choosing the target market middle to high class society by serving high quality coffee in this case using robusta coffee which has a more bitter taste than other coffees. In case of promotion activity, this coffee shop using media social like instagram as the platform of the promotion, at the other side is very helped by the role of television media that covered this coffee shop.
\end{abstract}

Key Words: communication strategy, marketing communication,customer

\begin{abstract}
Abstrak
Perkembangan bisnis di Indonesia semakin berkembang terlebih di bidang Kuliner. Tidak bisa dipungkiri bahwa semakin banyak Restoran dan Kafe yang ada di sekitar kita. Pebisnis berlomba-lomba untuk menciptakan sesuatu yang unik untuk menarik perhatian pelanggannya. Penelitian ini bertujuan mengetahui strategi komunikasi pemasaran yang telah dilakukan oleh Guten Morgen Coffee Lab and Shop untuk menarik konsumen. Penelitian ini menggunakan konsep komunikasi pemasaran. Dalam menganalisis data terhadap penelitian ini menggunakan analisis data interaktif. Selain menggunakan observasi dan studi pustaka, peneliti juga melalukan wawancara tidak terstruktur dengan pemilik dari kedai kopi dan konsumen untuk mendukung data penelitan. Hasil penelitian yang ditemukan bahwa kedai kopi ini dalam melakukan strategi komunikasi pemasarannya dengan memilih target pasar masyarakat menengah ke atas dengan menyajikan kopi yang berkualitas yakni menggunakan kopi robusta yang memiliki rasa lebih pahit daripada kopi lainnya. Dalam kegiatan promosi, kedai kopi ini memanfaatkan media sosial Instagram sebagai sarana promosinya, kemudian sangat terbantu oleh peran media televisi yang melakukan peliputan mengenai kedai kopi ini.
\end{abstract}

Kata Kunci : Strategi komunikasi, komunikasi pemasaran, konsumen

\section{Pendahuluan}


Perkembangan bisnis di Indonesia sekarang semakin meningkat, terlihat dari semakin banyaknya pelaku bisnis di berbagai bidang, seperti bidang teknologi, fashion, otomotif, kuliner dan lain sebagainya. Kemajuan pelaku bisnis yang paling terlihat dari bidang kuliner. Contohnya semakin banyaknya Warung Makan, Kafe, Restoran, dan Kedai Kopi baru yang bermunculan di tengah persaingan bisnis yang ketat. Persaingan bisnis di dunia kuliner ini tentunya menjadi tantangan tersendiri untuk para pelaku bisnis, dikarenakan mereka yang ingin membuka Warung Makan, Kafe, Restoran dan Kedai Kopi harus memiliki ciri khas yang unik atau sesuatu yang berbeda dari para pesaingnya. Pelaku bisnis harus bisa membaca pasar, menentukan targetnya, dan tujuan bisnis yang dijalankan agar bisisnya dapat terealisasikan dengan baik.

Kedai kopi merupakan suatu tempat untuk semua orang yang datang untuk meminum segelas kopi atau untuk berbincang-bincang kepada teman-teman. Berbeda dengan dulu, kedai kopi hanyalah sebagai tempat untuk minum kopi, tetapi sekarang peran dari kedai kopi dapat sebagai tempat untuk rapat antara perusahaan satu dengan yang lain, tempat untuk mengerjakan tugas, sebagai tempat untuk berdikusi, dan sebagai tempat untuk bersantai dan berbincang-bincang dengan teman. Kedai kopi salah satu bisnis yang sangat diminati oleh pebisnis muda masa kini. Bisnis kedai kopi merupakan suatu bisnis yang sifatnya santai, menarik dan bisa dinikmati oleh semua kalangan. Tidak bisa dipungkiri bahwa bisnis kopi sebagai terlihat menguasai pasar anak muda zaman sekarang seperti banyaknya kehadiran kedai kopi dari satu wilayah ke wilayah lainnya.

Guten Morgen Coffee Lab and Shop, berlokasi di Jalan Mandala Utara No. 29 C, Tomang, Grogol Petamburan, Jakarta Barat. Kedai kopi ini mempunyai ciri khas di bagian desain interior, yakni dengan bernuasa gaya homey dan botanical. Desain interior bergaya homey dan botanical adalah desain yang berasa seperti di rumah dengan suasana yang dekat dengan alam, dengan menggunakan elemen dari segi udara, pencahayaan dan bahan baku seperti kayu, bunga, dedaunan dan lain sebagainya. Kedai kopi yang satu ini memang terlihat sama secara visual dengan kedai kopi lainnya. akan tetapi yang membedakannya adalah ada salah satu aktivis anti narkoba bernama Yerry Pattinasarany yang dulunya Beliau juga sebagai pecandu narkoba yang ikut dalam terbentuknya kedai kopi ini.

Jadi, kedai kopi ini memperkerjakan beberapa mantan pecandu narkoba sebagai barista. Sebelum bekerja mereka (calon pekerja) diberi bekal edukasi tentang tata cara pembuatan kopi, memasak, membersihkan kedai kopi dan lain sebagainya. Di kedai kopi ini juga memberikan bimbingan konseling kepada para pekerja yang ingin melakukan konseling. Keunikan dari Guten Morgen Coffee Lab and Shop ini dengan merekrut mantan pecandu narkoba yang dijadikan sebagai barista. Dengan adanya aksi sosial yang dilakukan oleh aktivis anti narkoba Yerry Pattinasarany ini memberikan peluang untuk mantan pecandu narkoba untuk berhenti memakai obat terlarang dan berubah menjadi seseorang yang lebih baik.

Komunikasi massa diartikan sebagai jenis komunikasi yang ditujukan kepada khalayak tersebar, heterogen dan menimbulkan media alat-alat elektronik sehingga pesan yang sama dapat diartikan secara serempak dan sesaat. Maka komunikasi yang ditujukan kepada massa dengan menggunakan media elektronik khususnya televisi merupakan komunikasi massa (Rakhmat, 2009).

Dalam penelitian ini, aksi sosial yang dilakukan dari Guten Morgen Coffee Lab and Shop disoroti oleh salah satu jenis media massa yakni televisi.. Beberapa acara televisi seperti Big Circle Show, Talk show yang membahas topik bisnis yang 
berdampak sosial bagi masyarakat yang tayang setiap Hari Minggu, Pukul 19.05 WIB. Selamat Pagi Indonesia, acara gelar wicara yang ditayangkan setiap Hari Senin hingga Jumat Pukul 09.50 - 10.00 WIB. Kedua acara tersebut merupakan salah satu program acara di stasiun televisi Metro Tv. Tidak hanya di satu stasiun televisi, BeritaSatu Tv dalam program acara People and Inspiration. Program yang mengangkat sosok atau profil anak muda "inspiring", lembaga atau komunitas yang kegiatannya berdampak positif dan menginspirasi masyarakat luas. Dengan sudah adanya beberapa acara televisi yang meliput kedai kopi ini, secara langsung telah memberikan kesadaran merek (brand awareness) kepada masyarakat terhadap kedai kopi ini.

Keunikan dari latar belakang terbentuknya kedai kopi ini menjadikan suatu hal yang perlu diteliti. Oleh sebab itu dengan pemaparan latar belakang masalah penulis memutuskan untuk meneliti bagaimana Guten Morgen Coffee Lab and Shop melakukan strategi komunikasi pemasaran dalam membangun brand awareness kepada masyarakat.

Tinjauan teoretis, komunikasi (dari bahasa Inggris “communication”), secara etimologis atau menurut asal katanya adalah dari bahasa Latin communicates, dan perkataan ini bersumber pada kata communis. Dalam kata communis sini memiliki makna "berbagi" atau "menjadi milik bersama' yaitu suatu usaha yang memiliki tujuan untuk kebersamaan atau kesamaan makna (Ngalimun, 2017)

Cara yang baik untuk menerapkan kegiatan komunikasi ialah 1) who, siapa komunikatornya? 2) says what, pesan apa yang diinformasikan? 3) In which channel, media apa yang ingin digunakannya? 4) to whom, siapa komunikannya? 5) with what effect, efek apa yang diharapkan (Laswell, 2012).

Strategi komunikasi pada hakikatnya adalah perencanaan (planning) dan manajemen (management) untuk mencapai satu tujuan. Strategi komunikasi merupakan panduan dari perencanaan komunikasi dan manajemen komunikasi untuk mencapai satu tujuan (Effendy, 2003)

Strategi komunikasi pemasaran memiliki tiga konsep penting, yaitu; 1) Segmentasi pasar merupakan proses pengategorian atau pembagian konsumen ke dalam profil segmen yang berbeda-beda. 2) Target pasar adalah proses memilih segmen pasar yang paling potensial, atau yang paling sesuai, atau yang paling mungkin untuk dijadikan target pasar. 3) Positioning sangat penting karena ia menegaskan posisi brand atau produk di antara brand yang lain. Ia berfungsi untuk membedakan dirinya dari kompetitor yang ada pada pikiran konsumen (minds of consumers) (Suwatno, 2017).

Terdapat empat komponen dalam bauran pemasaran yang biasa dikenal 4P, yakni sebagai berikut; 1) Produk (product), mutu produk menunjukkan kemampuan sebuah produk untuk menjalankan fungsinya; ciri produk merupakan sarana kompetitif untuk membedakan produk perusahaan dengan produk pesaing, sedangkan desain dapat menyumbangkan kegunaan atau manfaat produk serta coraknya. 2) Harga (price), sistem manajemen perusahaan akan menentukan harga dasar yang tepat bagi produk atau jasa yang dihasilkan oleh perusahaan. 3) Distribusi (place) sebagaian besar produsen menggunakan perantara pemasaran untuk memasarkan produk, khususnya barang dengan cara membangun suatu saluran distribusi, yaitu sekelompok organisasi yang saling tergantung dalam proses yang memungkinkan suatu produk tersedia bagi penggunaan atau konsumsi oleh konsumen atau pengguna industrial. 4) Promosi (promotion), untuk mengkomunikasikan produk perlu disusun suatu strategi yang sering disebut dengan 
strategi bauran promosi (promotion mix) yang terdiri dari atas empat komponen utama, yakni periklanan (advertising), promosi penjualan, (sales promotion), hubungan masyarakat (public relations), dan penjualan perseorangan (personal selling). Promosi adalah suatu unsur yang digunakan untuk memberitahukan dan membujuk pasar tentang produk atau jasa yang baru pada perusahaan, hak dengan iklan, penjualan pribadi, promosi penjualan, ataupun dengan publisitas. (Kotler dan Amstrong, 2012)

Perilaku konsumen adalah studi unit pembelian dan proses pertukaran yang melibatkan perolehan, konsumsi dan pembuatan barang, jasa, pengalaman, serta ide. (Kotler, 2005)

\section{Metode Penelitian}

Dalam penelitian ini penulis memilih metode penelitian kualitatif, bahwa penelitian kualitatif adalah penelitian yang bertujuan untuk memahami fenomena yang dialami oleh subjek penelitian melibatkan perilaku, persepsi, motivasi, tindakan, dan kemudian dideskripsikan dalam bentuk kata-kata pada suatu konteks khusus dan menggunakan metode alamiah. (Moleong, 2009) dengan pendekatan studi kasus. Metode penelitian studi kasus memungkinkan penulis untuk mencari, menggali, dan mempelajari strategi komunikasi pemasaran yang dilakukan kedai kopi Guten Morgen dalam membangun brand awareness kepada masyarakat. Untuk memperkuat data penelitian maka, penulis menggunakan metode pengumpulan data dengan melakukan wawancara, observasi, dokumentasi dan studi kepustakaan dalam penelitian ini. Dalam penelitian ini, yang menjadi subjek penelitian penulis adalah pemilik kedai kopi Guten Morgen dan yang menjadi objek penelitian adalah pelanggan yang sering datang mengunjungi kedai kopi.

Penulis disarankan oleh Van Kenny Tamara selaku pemilik dari kedai kopi untuk menghubungi kontak konsumen yang telah diberikan. Karena ketiga konsumen ini merupakan pelanggan yang terlihat sangat sering datang dengan rentang waktu sedikitnya satu sampai dua kali paling sedikit datang ke kedai kopi.

\section{Hasil Temuan dan Diskusi}

Disebutkan dalam visinya kedai kopi ini ingin menjadi kedai kopi yang baik untuk pemilik kedai kopi lainnya, lalu disebutkan pula pada misinya dari kedai kopi ini ingin tetap berkelanjutan dan berperan dalam bidang kedai kopi di Indonesia.

Pada bagian cara yang baik dalam menerapkan komunikasi, komunikator yang dimaksud adalah pemilik dari Guten Morgen Coffee Lab and Shop yakni Van Kenny Tamara, Yerry Pattinasarany dan Igor Sitompul. Alasan mereka membangun kedai kopi ini karena latar belakang mereka jauh dari kata sempurna. Van Kenny Tamara mengatakan bahwa Yerry Pattinasarany sudah hampir dua kali ingin meninggal karena narkoba dan juga ada tekanan pada saat itu Bapaknya meninggal. Kemudian masuk rehabilitasi karena narkoba. Igor Sitompul juga hampir meninggal karena overdosis narkoba dan kemudian masuk rehabilitasi. Van Kenny Tamara juga dulunya alcoholic yakni kecanduan minuman keras atau alkohol dan hampir ada broken family. Akibat kecanduan minuman alkohol itu menyebabkan pernah mengalami kecelakaan sampai mobilnya hancur dan sudah pernah dua kali masuk rehabilitasi karena alkohol. Setelah mereka bertiga melewati masa rehabilitasi, akhirnya mereka berubah untuk menjadi pribadi yang baik. 
Dari latar belakang yang kelam itu, akhirnya mereka ingin hidup mereka berdampak baik dengan orang lain, kemudian tercetus sebuah pemikiran untuk membuka kedai kopi Guten Morgen dengan memperkerjakan mantan pecandu narkoba. Van Kenny Tamara mengatakan bahwa alasan mereka ingin menggunakan mantan pecandu narkoba sebagai pegawai di kedai kopi ini karena dulunya juga mereka bertiga dari latar belakang yang sama yaitu mantan pecandu narkoba dan alkohol. Karena latar belakang mereka yang sama, mereka bertiga ingin ikut serta membantu para mantan pecandu narkoba ini untuk sembuh dengan cara bekerja di kedai kopi ini.

Pesan yang ingin disampaikan meliputi menu makanan dan minuman, pesan ini disampaikan untuk para calon pelanggan agar mengetahui makanan dan minuman apa saja yang dijual oleh kedai kopi ini. Suasana di kedai kopi, ingin memberitahukan kepada calon pelanggan agar mengetahui suasana dan dekorasi yang dipakai oleh kedai kopi Guten Morgen. Untuk konten "we are hiring", informasi ini sangat berguna untuk seseorang yang sedang mencari pekerjaan. Lalu, kedatangan beberapa selebgram dan artis, dan konten event seperti adanya pameran dan live music di kedai kopi ini.

Media yang digunakan dalam melakukan pemasaran bahwa Van Kenny Tamara selaku pemilik dari kedai kopi Guten Morgen ini mengatakan bahwa untuk melakukan pemasaran mengenai kedai kopinya hanya menggunakan media sosial Instagram. Alasannya menggunakan Instagram karena sangat mudah digunakan dan gratis. Karena Instagram juga merupakan salah satu media sosial yang saat ini paling banyak digunakan oleh sebagian orang.

Untuk komunikannya, seperti yang dikatakan oleh Yerry Pattinasarany pesan yang ingin sampaikan ditujukan kepada calon pembeli yang merupakan pegawai kantor dan anak-anak kuliah. Karena secara letak geografis, letak kedai kopi ini dekat dengan banyaknya kantor dan kampus yang ada. Lalu, pesan yang sampaikan juga ditujukan kepada semua pengguna akun Instagram baik yang mengikuti akun Instagram Guten Morgen atau pun tidak. Dalam penyampaian pesan ini bersifat universal yang ditujukan kepada semua orang, karena tidak ada batasan umur seseorang untuk datang ke kedai kopi ini.

Pada bagian ini, efek yang diharapkan oleh para pemilik yaitu Van Kenny Tamara mengatakan lihatlah kedai kopinya bukan hanya ingin mendapatkan profit dan berorientasi kepada bisnis tetapi mereka juga ingin berbuat baik kepada sesama dan dengan adanya kedai kopi ini berharap bisa memberikan semangat pagi dan rasa nyaman kepada calon pelanggan yang datang dengan mendapatkan ucapan selamat pagi dari barista dan menikmati suasana kedai kopi yang nyaman didukung dekorasi yang homey dengan bunga, tanaman dan dedaunan lainnya.

Kemudian untuk strategi komunikasi pemasaran memiliki tiga konsep penting, yaitu; seperti yang dikatakan oleh Yerry Pattinasarany bahwa dalam pemilihan segmentasi dilihat dari segi geografinya yakni dari wilayahnya, orang-orang yang berlokasi berjarak kurang lebih lima kilometer dari kedai kopi. Dikarenakan banyak kantor dan kampus yang dekat dengan kedai kopi ini. Selanjutnya Van Kenny Tamara mengatakan pemilihan segmentasi dilihat dari segi psikologisnya yaitu kelas sosial dan sikap pada produk, memilih masyarakat yang kelas sosialnya dari kelas menengah ke atas dan menyukai kopi dengan rasa yang lebih pahit daripada kopi dengan rasa yang lebih asam. Dijelaskan bahwa alasan memilih segmentasi kelas menengah ke atas dikarenakan tidak ingin bersaing dengan kopi dengan harga belasan ribu rupiah seperti Kopi Tuku dengan permainan segmentasi kelas menengah 
kebawah. Karena jika bersaing dengan segmentasi kelas menengah kebawah tidak ada yang membedakan kedai kopi ini dengan kedai kopi lainnya.

Sesuai dengan pemilihan segmentasi pasarnya, target pasar yang ditujukan merupakan pegawai kantor dan anak kampus karena kedai ini berlokasi dekat dengan banyak kantor dan kampus. Yerry Pattinasarany menjelaskan bahwa rata-rata orang yang datang ke kedai kopi ini merupakan orang yang berlokasi kurang lebih berjarak lima kilometer dari kedai kopi. Kemudian disampaikan pula oleh Van Kenny Tamara, target pasar yang ditujukan adalah masyarakat dengan kelas sosial menengah ke atas antara lain kelas B, B+, A dan A+. Dijelaskan bahwa alasan memilih target pasar dengan kelas sosial menengah ke atas karena, kedai kopi ini bukan memasarkan harga kopinya dengan harga belasan ribu rupiah melainkan dengan harga puluhan ribu rupiah. Karena pemilihan produk kopi yang dipakai oleh kedai kopi ini merupakan jenis kopi dengan pilihan terbaik dan tidak ingin memakai kopi yang sembarangan.

Positioning yang dilakukan oleh kedai kopi ini, ingin menunjukkan kepada masyarakat kalau kedai kopi ini menggunakan kopi yang berkualitas. Karena pemilik dari kedai kopi ini tidak ingin sembarangan dalam menggunakan kopi yang akan diberikan kepada konsumennya. Kopi yang dipakai adalah kopi robusta yang terkenal dengan rasa yang pahit dan kopi khas Indonesia. Kemudian, ingin menunjukkan kepada masyarakat jika kedai kopi ini menerima konsumen yang berbagi cerita atau masalah yang dihadapi dan kemudian bisa langsung berkonsultasi atau berbicara dengan pemilik kedai kopi ini. Serta menempatkan kedai kopi ini mampu memberikan semangat pagi kepada siapapun yang datang ke kedai kopi ini.

Empat komponen dalam bauran pemasaran, yakni sebagai berikut; dalam segi produk, menurut Van Kenny Tamara selaku pemilik Guten Morgen Coffee Lab and Shop ini menjelaskan yang membedakan kedai kopinya dengan kedai kopi lain dari segi kopi adalah menggunakan kopi robusta. Selanjutnya dijelaskan pula jika dari segi makanan, mempunyai makanan andalan yaitu menu German Sausage (sosis Jerman) dan Chashu Donburi, yakni menggunakan daging perut babi dan ayam kemudian daging tersebut dipanggang dengan saus special dan disajikan dengan pasta cabai. Lalu, dari segi dekorasi, kedai kopi ini memakai konsep dekorasi homey yaitu suasana sepeti di rumah, botanical yakni perawatan yang bahan utamanya dari tanaman (herbal, akar, bunga, buah atau biji), bohemian adalah dekorasi yang tidak teratur, dan simple atau sederhana. Kemudian, dari segi pegawai, kedai kopi ini mempekerjakan beberapa mantan pecandu narkoba. Yerry Pattinasarany mengatakan, jika awal mula yang berinisiatif ingin mempekerjakan mantan pencandu narkoba ini adalah dia sendiri. Karena Yerry Pattinasarany ingin ikut serta berkontribusi untuk masyarakat membantu kaum-kaum yang notabennya sulit untuk bertahan dalam posisi yang sebagian orang dianggap sebelah mata

Dalam segi harga, Van Kenny Tamara mengatakan menempatkan harga produknya sesuai dengan pemilihan target pasarnya. Sesuai dengan target pasar dengan kelas sosial menegah ke atas, maka kedai kopi ini memasang harga untuk segelas kopinya kisaran Rp. 30.000,-an sampai Rp. 40.000,-an. Dan untuk makanan dari kisaran harga Rp 30.000,-an sampai dibawah Rp. 100.000,-an.

Dalam segi tempat, untuk tempat atau lokasi kedai kopi ini berlokasi di Mandala, Tomang Jakarta Barat. Alasan kedai kopi ini didirikan di daerah Mandala karena pada awalnya lantai dua diatas kedai kopi ini adalah tempat kerjanya Van Kenny Tamara. Kemudian, karena Van Kenny Tamara dan istri mempunyai bisnis 
properti dan bisnis toko bunga yang sering melakukan meeting dengan client di tempat kopi, maka terbentuklah suatu pemikiran untuk mendirikan kedai kopi dibawah kantornya. Dijelaskan pula jika Van Kenny Tamara juga melihat peluang jika pada saat itu belum ada kedai kopi yang berdiri di daerah Mandala, Tomang.

Dalam segi promosi, Van Kenny Tamara mengatakan bahwa dalam mempromosikan kedai kopinya ini hanya menggunakan media sosial Instagram. Instagram digunakan karena cara aksesnya yang mudah dan gratis. Instagram pun untuk saat ini merupakan salah satu media sosial yang sangat banyak digunakan oleh sebagian orang. Kemudian, pada saat Grand Opening tahun lalu, kedai kopi ini mengundang beberapa bloggers, karena diyakini mampu memberikan value lebih terhadap kedai kopi ini. Yerry Pattinasarany menambahkan jika dalam segi pemasaran sangat terbantu oleh media televisi yang melakukan peliputan di kedai kopi Guten Morgen. Semenjak hampir dua tahun terakhir, setiap bulannya ada stasiun televisi yang melakukan peliputan di kedai kopi ini.

Kemudian untuk memperkuat data peneliti, peneliti mewawancarai ketiga narasumber sebagai pelanggan dari kedai kopi ini. Ketiga narasumber tersebut bernama William Chandra, Michael Widjaja dan Marline. William Chandra mengatakan bahwa yang memperkuat kedai kopi ini adalah promosi yang dilakukan lewat media sosial Instagram. Ada beberapa temannya yang juga bercerita mengenai kedai kopi ini, dan yang membuat kedai kopi ini dikenal oleh banyak orang adalah dalam segi konsep dekorasi. Michael Widjaja mengatakan alasan lebih memilih kedai kopi Guten Morgen daripada kedai kopi lainnya dikarenakan keunikan dan kenyamanan dari suasana interiornya dan sudah saling kenal dengan para pekerja di kedai kopi ini. Marline mengatakan bahwa mengetahui kedai kopi Guten Morgen ini dari media sosial Instagram.

\section{Simpulan}

Guten Morgen Coffee Lab and Shop menerapkan komponen komunikasi dengan baik dan jelas. Dengan adanya latar belakang yang mendasari terbentuknya kedai kopi ini dengan mempekerjakan mantan pecandu narkoba menjadikan kedai kopi ini memiliki nilai tambah bagi masyarakat dari sisi sosial. Kedai kopi ini juga menerapkan strategi komunikasi pemasaran dengan pemilihan target pasar dengan masyarakat kelas menengah ke atas. Untuk kualitas produk, kedai kopi ini menggunakan kopi robusta, dikarenakan ingin menunjukkan kepada konsumen bahwa kedai kopi ini lebih ingin dikenal sebagai kedai kopi yang memiliki rasa kopi yang pahit daripada kedai kopi lainnya. Lalu, pemilik dari kedai kopi ini mengingikan agar kedai kopi ini bisa dikenal dapat memberikan semangat pagi dan bisa saling berbagi cerita antara konsumen dan pegawai atau dengan pemilik. Pemilik Guten Morgen Coffee Lab and Shop mempromosikan kedai kopinya hanya lewat media sosial Instagram, karena diyakini bahwa kebanyakan masyarakat zaman sekarang pasti menggunakan Instagram. Dan promosi lewat media sosial Instagram pun tidak memakan biaya yang tinggi dan sangat mudah untuk diakses oleh siapapun. Kemudian, kedai kopi ini juga terbantu dalam pemasarannya lewat media konvensional televisi di beberapa acara program televisi yang melakukan peliputan di kedai kopi tersebut. Bagi penulis, kedai kopi ini dikenal sebagai kedai kopi yang memiliki dekorasi yang unik dan menarik. Dari beberapa konsumen yang penulis wawancarai mereka sangat nyaman di kedai kopi ini dikarenakan dekorasi kedai kopi 
ini membuat mereka nyaman dan barista di kedai kopi ini sangat bersosialisasi dengan konsumen.

\section{Ucapan Terima Kasih}

Penulis mengucapkan terima kasih kepada Tuhan YME, dosen pembimbing, orang tua, teman-teman serta kepada narasumber yang menjadi subjek dan objek penelitian serta seluruh pihak yang telah membantu penulis menyelesaikan penulisan skripsi ini baik secara langsung maupun tidak langsung.

\section{Daftar Pustaka}

Moleong, Lexy J. (2012). Metodologi Penelitian Kualitatif. Bandung : PT Remaja Rosdakarya.

Priansa, Donni Juni. (2017). Komunikasi Pemasaran Terpadu. Bandung: Pustaka Setia.

Rakhmat, Jalaluddin. (2009). Metode Penelitian Komunikasi. Bandung: PT Remaja Rosdakarya.

Soemanagara. (2012). Strategic Marketing Communication. Bandung : Alfabeta

Suwatno, (2017). Komunikasi Pemasaran Kontekstual. Bandung : Simbiosa Rekatama

Wahid, U., \& Puspita, A. (2017). Upaya Peningkatkan Brand Awareness PT. Go-Jek Indonesia Melalui Aktivitas Marketing Public Relations. Jurnal Komunikasi, 9(1), 31-43. Retrieved

from https://journal.untar.ac.id/index.php/komunikasi/article/view/265/641

http://romeltea.com/media-massa-makna-karakter-jenis-dan-fungsi/Media. 